\title{
Review of the Survey's activities in 1986
}

\author{
Martin Ghisler \\ Director
}

The Geological Survey of Greenland (GGU) continued in 1986 the systematic investigation of the geology of Greenland. The work comprises geological mapping and basic research as well as applied geology and geophysics (fig. 1). The long term purpose is to establish the necessary geological background for evaluation of the potential of the non-living resources.

The scientific and technical staff of 112 based in Copenhagen and 87 participating in the field work in Greenland carried out programmes of geological mapping and investigation, glaciological investigations, and mineral and oil assessments which included geochemical and geophysical methods.

In April 1986 GGU celebrated its 40th anniversary. A special publication dedicated to GGU's former director, K. Ellitsgaard-Rasmussen, was issued which covers different aspects of the Survey's work in the developments in Greenland geology over the past ten years (Rapp. Grønlands geol. Unders. 128).

\section{East Greenland}

GGU had substantial field activity in two areas in East Greenland, involving about 40 participants. One group, operating out of Mesters Vig, studied the geology of the sedimentary basin north of Jameson Land, mainly on Traill $\varnothing$ and Geographical Society $\emptyset$ where, among other activities, shallow cores were drilled for petroleum source rock analyses. The distribution of lead originating from mining and shipping of ore concentrate in the $1950 \mathrm{~s}$ was investigated in the bottom sediments of Kong Oscar Fjord near Mesters Vig.

Regional geological investigations were undertaken from a base camp near Ammassalik as part of the 1:500 000 geological mapping programme of southern East Greenland. A minor group based near Kangerdlugssuaq studied the stratigraphy of the southern part of the Tertiary basalts. A reconnaissance survey of the mineral potential formed part of GGU's activity in both areas.

\section{West Greenland}

In West Greenland the field activities were concentrated around Disko Bugt and in the Godthåb area.

In preparation for detailed geological investigations in the Disko Bugt area with special emphasis on evaluation of the mineral potential, a regional geochemical stream sediment sampling programme was carried out in the Jakobshavn area. On Disko and Nûgssuaq the investigation of the Tertiary basalts and associated sediments was continued. As part of the 


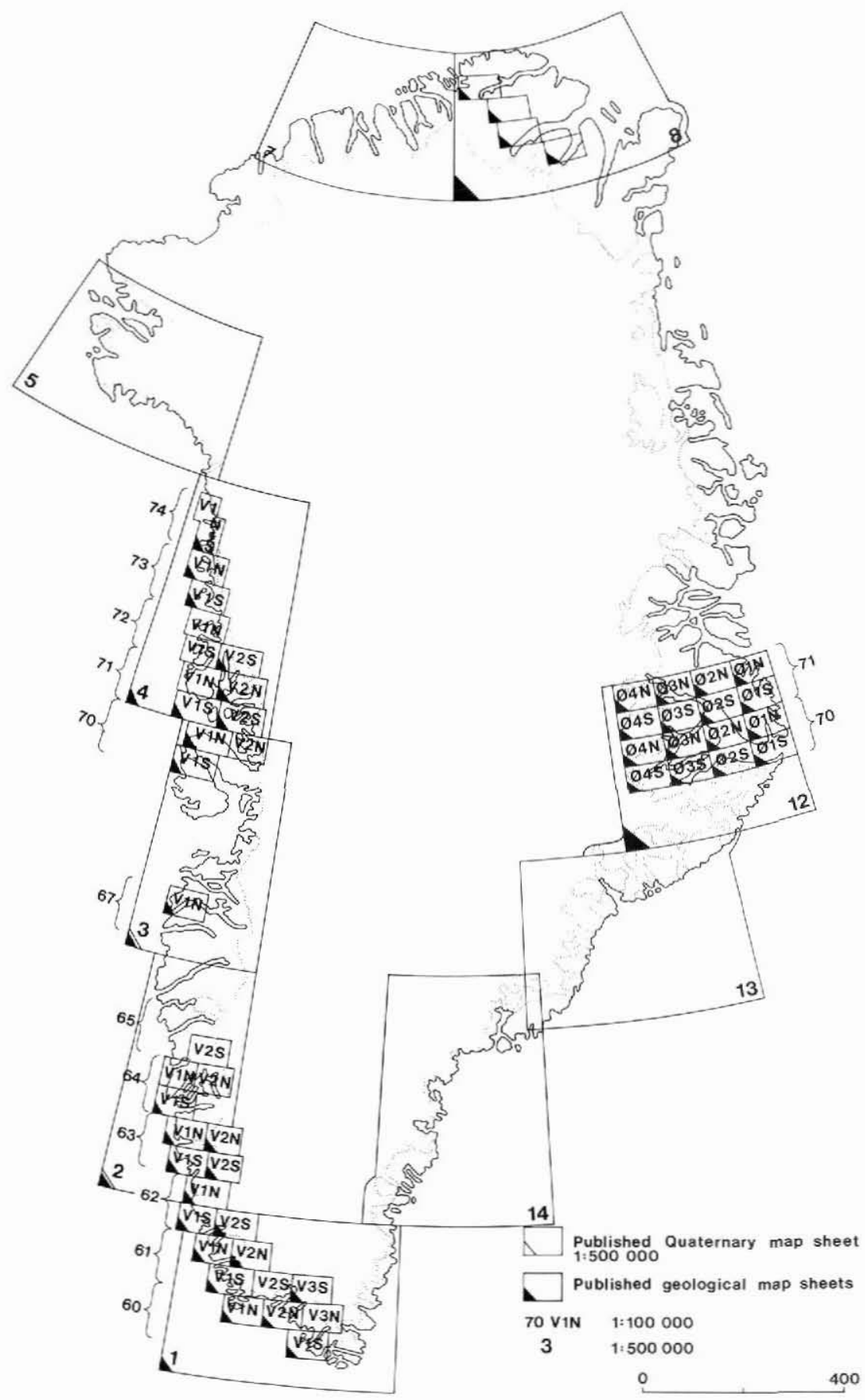

Fig. 2. Map sheets published and in preparation by the Survey (see inside back cover). 
hydropower development programme in the area the topography of the base of the ice margin and its thickness was investigated with radar-sounding techniques. The glaciological investigations near Jakobshavn were continued from previous years.

Glaciological and hydrological data were collected continuously at GGU's two stations east of Godthåb (Qamanârssûp sermia) and south of Søndre Strømfjord (Tasersiaq) from late May to early September with additional work near Sukkertoppen Iskappe.

The geological mapping of the 1:100 000 Fiskefjord sheet (64 V.1 Nord) was continued. The work included sampling of heavy mineral concentrates. The sampling of stream sediments, as part of the regional geochemical programme, was also accomplished in the area north of Godthåbsfjord. Selected areas between Godthåbsfjord and Fiskenæsset with scheelite and base metal anomalies found in previous years were studied in detail.

\section{South Greenland}

The area between Ivituut and Kobberminebugt was investigated with special emphasis on the occurrence of sulphides and associated gold and silver mineralization.

Special uranium investigations in South Greenland with support from the Danish Ministry of Energy were completed. The EEC supported project on the pyrochlore mineralization connected with the syenites around Motzfeldt $S \varnothing$ in the Igaliko complex was also completed. An excursion to the Motzfeldt mineralization was arranged in August with participants from interested mining companies and Greenland and Danish authorities.

\section{General}

GGU assisted the Mineral Resources Administration with geological and environmental inspection of Greenex's exploitation of the Black Angel lead-zinc mine at Maarmorilik and with the evaluation of geophysical/geological data from Jameson Land collected by ARCO.

GGU inspected the mineral exploration activities of concessionaires at Ivituut, Narsaq and Kangerdluarssuk in South Greenland and Kangerdlugssuaq in East Greenland. Assistance was also provided to the Mineral Resources Administration in the evaluation of private company reports and applications for concessions.

GGU has prepared a draft for a six-year programme of marine-seismic investigations offshore Greenland. The programme (KANUMAS) is intended to be carried out and financed by private mining companies in collaboration with Nunaoil A/S and GGU.

During the year the 1:500 000 geological map of Peary Land was printed together with four map sheets from the area at a scale of 1:100 000. The last of sixteen 1:100 000 map sheets covering the Scoresby Sund region appeared (fig.2). Five Reports, one Bulletin and one Map Sheet Description were published. As a result of GGU activities some forty contributions appeared in 1986 in international scientific journals. Two contributions in Danish appeared in GGU's new popular series 'Geologi i Grønland'. Late in 1986 GGU was equipped with new modern computing facilities for both scientific and administrative purposes, specially funded by the Ministry for Greenland. 